\title{
Near Fault Effect on the Response of Single Hinged Compliant Offshore Tower
}

\author{
Syed Yusuf Javed ${ }^{1, *}$ \\ ${ }^{1}$ MTECH, Department of Civil Engineering, Aligarh Muslim University
}

\begin{abstract}
The response of compliant offshore structure under simultaneous action of random waves and earthquake loading has been analyzed. Since earthquake forces play a significant role in affecting the response of these offshore structures, comparative studies have been carried out considering near fault and far fault seismic excitations in the presence of moderate random sea waves. The offshore tower is modeled as an inverted pendulum with a cylindrical shaft connected by an articulated joint at the base. Seismic forces are evaluated by dividing the tower shaft into finite elements with masses lumped at the nodes. The nonlinearities associated with the system owing to variable submergence, drag force, variable buoyancy along with the geometry are considered in the analysis. The nonlinear dynamic equation of motion is formulated considering Lagrangian approach, which is solved in time domain by the Newmark-beta integration scheme. The sea state conditions, more precisely the water particle kinematics are evaluated using Airy's wave theory along with the stretching modifications, as suggested by Chakrabarti. To minimize the dynamic responses, emphasis has to be given to the variations in height and position of the buoyancy chamber in extreme wave condition. The results are expressed in the form of time histories of deck displacement, hinge rotation, hinge shear and the bending moment. Parameters like maximum, minimum, mean and standard deviation are also determined by statistical analysis of response time histories of the dynamic responses at articulated joint.
\end{abstract}

\section{Introduction}

The aim of this paper is to analyze the compliant platform to hydrodynamic loads, in order to minimize the dynamic responses. Emphasis has been given to the variations in height and position of the buoyancy chamber towards the maximum response in random waves. The behaviour of these structures is nonlinear and difficult to analyse as different combinations of environmental forces can act simultaneously on these towers. Hence, compliant structures are analysed using dynamic approach, which involves determination of various parameters and their dynamic responses. In order to have a comparative study considering near-fault and far-fault seismic excitation along with moderate sea waves, random vibration analysis of the platform subjected to the simultaneous action of moderate random wave and earthquake loading has been performed. The present work also gives further suggestions regarding the need and research of offshore compliant structures.

\section{Literature review}

Many investigation had already been carried out on offshore compliant structures by various researchers Penzien (1972) analysed stochastic response of offshore towers due to random waves and strong motion earthquakes. Chakrabarti (1979) analysed motion of compliant offshore tower. Hana (1988) investigated the dynamic response of a compliant tower with multiple articulation. Patrick (1997) discussed about the nonlinear and stochastic response of these compliant structures. R.Adrezin (1990) also analysed the dynamic response of these towers. Mohd. Moonis Zaheer (2007) investigated the response of a double pendulum compliant offshore Tower to collinear wave and current Forces. Professor Danish Hasan (2011) investigated multi hinged compliant structure under vertical ground excitations taking into consideration the effects of earthquake on the response of these towers.

\footnotetext{
${ }^{1}$ Corresponding author: author@email.org
} 


\section{Elucidation of the problem}

The analysis of the offshore compliant tower is done by considering the structure as pendulum which has been inverted containing mass lumped at one end. It can be considered quite similar to a cantilever structure acted by various forces. Whereas the other end is connected to a massless spring having zero stiffness since the foundation of the structure is assumed to be congregated together. The model can be restricted to rotate in XY plane without any translational motion hence the model is idealized as single degree of freedom system for analysis. The dimensions of shaft are cylindrical in shape which makes this model "hydrodynamic transparent body". The top end of this shaft consist of deck which is rigidly fixed and its elevation is above still water surface level. Here the effect of soil structure interaction has been neglected that is seismic response of structure on foundation has not been taken into account. The analysis of water waves and near fault effect has been separately studied. The water particle kinematics that is the horizontal and vertical component of velocity and acceleration are considered zero at the initial boundary condition during seismic analysis.

\begin{tabular}{|l|l|}
\hline \multicolumn{2}{|c|}{ Details of Compliant Offshore Model } \\
\begin{tabular}{|l|l|}
\hline Height of compliant tower & $400 \mathrm{~m}$ \\
\hline Depth of water & $350 \mathrm{~m}$ \\
\hline Top mass of deck & $2000000 \mathrm{~kg}$ \\
\hline Height of buoyancy chamber & $70 \mathrm{~m}$ \\
\hline Position of buoyancy chamber & $270 \mathrm{~m}$ \\
\hline Height of ballast chamber & $120 \mathrm{~m}$ \\
\hline Mass of ballast chamber & $44840 \mathrm{~kg} / \mathrm{m}$ \\
\hline \multicolumn{2}{|c|}{ Details of diameter } \\
\hline \multicolumn{2}{|l}{} \\
\hline For tower's buoyancy chamber & $20 \mathrm{~m}$ \\
\hline \hline Diameter for buoyancy,d1 & $7.50 \mathrm{~m}$ \\
\hline Diameter for added mass,da1 & $20 \mathrm{~m}$ \\
\hline Diameter for drag,dd & $7.50 \mathrm{~m}$ \\
\hline Diameter for inertia,di & \\
\hline For tower's shaft & $7.50 \mathrm{~m}$ \\
\hline \hline Diameter for buoyancy,d2 & $4.50 \mathrm{~m}$ \\
\hline Diameter for added mass,da2 & $17.0 \mathrm{~m}$ \\
\hline Diameter for drag,dd2 & $4.50 \mathrm{~m}$ \\
\hline Diameter for inertia,di2
\end{tabular}
\end{tabular}

Fig. 1. Details of Dimensions of SHAT model

\section{Purlieu influence}

In additional to wave and current forces acting on the tower, the contribution of near fault and far fault effect on the offshore compliant structure has been taken into account while analysing the complex behaviour of the structure. The seismological characteristics of selected ground motion earthquake records has been taken into consideration with magnitude equal or greater than 6 . The time history of near fault Imperial valley 1979, Morgan Hill 1984, Duzce Turkey 1990 and their far fault has been chosen to analyse the responses. In random wave analysis we compute wave scattered diagram which depends on the location where the platform to be installed. From this diagram we consider a wave spectrum which takes into account the performance of the structure closely in terms of frequency domain approach. This wave spectral method is called random wave analysis. This approach helps to analyse the hydrodynamic loading on the deep offshore structure. This is a statistical approach in which most probable wave force acting in the life time of the structure. So we can conclude that in both the analysis the most important parameter is sea surface elevation, that defines the water particle velocity and acceleration. In order to calculate the maximum wave or more precisely the sea surface elevation we may go for linear wave theory or high order wave theories. These waves are considered to be made up of infinite number of wavelets which are having different frequencies in random phase, generating a long crested sea as they move in the direction of load. As suggested by Chakrabarti, the random sea surface elevation has been analysed using DNV version of Pierson Moskovitz (P-M). 


\begin{tabular}{|c|c|c|c|c|c|c|c|}
\hline $\begin{array}{c}\text { S.N } \\
\text { o }\end{array}$ & $\begin{array}{c}\text { Earthquak } \\
\mathrm{e}\end{array}$ & $\begin{array}{l}\text { Mechan } \\
\text { ism }\end{array}$ & Station & $\begin{array}{c}\text { Compone } \\
\text { nt }\end{array}$ & $\begin{array}{c}\text { Magnitud } \\
\text { e } \\
\text { Mw }\end{array}$ & $\begin{array}{c}\text { DISTANC } \\
\text { E } \\
\operatorname{Rf}(\mathbf{k m})\end{array}$ & $\begin{array}{c}\text { Duration } \\
\text { (s) } \\
\text { (recordin } \\
\text { g time } \\
\text { step) }\end{array}$ \\
\hline 1. & $\begin{array}{l}\text { Morgan } \\
\text { Hill }\end{array}$ & $\begin{array}{l}\text { Strike- } \\
\text { Slip }\end{array}$ & Capitola & CAP132 & 6.19 & 39.08 & $\begin{array}{l}35.995(0 . \\
010)\end{array}$ \\
\hline 2. & $\begin{array}{l}\text { Imperial } \\
\text { Valley }\end{array}$ & $\begin{array}{l}\text { Strike- } \\
\text { Slip }\end{array}$ & $\begin{array}{l}5059 \text { El Centro } \\
\text { Array }\end{array}$ & $\begin{array}{l}\text { H- } \\
\text { E13140AT } \\
2\end{array}$ & 6.50 & 21.99 & $\begin{array}{l}39.500(0 . \\
005)\end{array}$ \\
\hline 3. & $\begin{array}{l}\text { Duzce, } \\
\text { Turkey }\end{array}$ & $\begin{array}{l}\text { Strike- } \\
\text { Slip }\end{array}$ & Mudurnu & $\begin{array}{l}\text { MDR000A } \\
\text { T2 }\end{array}$ & 7.14 & 40.99 & $\begin{array}{l}28.820(0 . \\
005)\end{array}$ \\
\hline 4. & $\begin{array}{l}1979 \\
\text { Imperial } \\
\text { Valley, CA }\end{array}$ & $\begin{array}{l}\text { Strike- } \\
\text { slip }\end{array}$ & $\begin{array}{l}5058 \mathrm{El} \\
\text { Centro Array } \\
\text { Number } 11\end{array}$ & H-E11140 & 6.53 & 12.60 & $\begin{array}{l}39.030(0 . \\
005)\end{array}$ \\
\hline 5. & $\begin{array}{l}\text { 1984,Morg } \\
\text { an Hill, CA }\end{array}$ & $\begin{array}{l}\text { Strike- } \\
\text { slip }\end{array}$ & $\begin{array}{l}47381 \text { Gilroy } \\
\text { Array } \\
\text { Number } 3\end{array}$ & G03000 & 6.19 & 13.02 & $\begin{array}{l}39.995(0 . \\
005)\end{array}$ \\
\hline 6. & $\begin{array}{l}1990 \text { Duzce } \\
\text { Turkey }\end{array}$ & $\begin{array}{l}\text { Strike- } \\
\text { slip }\end{array}$ & 1062 Lamont & $1062-n$ & 7.14 & 13.30 & $\begin{array}{l}42.320(0 . \\
01)\end{array}$ \\
\hline 7. & $\begin{array}{l}1994 \\
\text { Northridge, } \\
\text { CA }\end{array}$ & Reverse & $\begin{array}{l}\text { 24157LA- } \\
\text { Baldwin Hills }\end{array}$ & BLD360 & 6.70 & 31.30 & $\begin{array}{l}39.500(0 . \\
02)\end{array}$ \\
\hline
\end{tabular}

Fig. 2. Seismological characteristics of selected ground motion records.(source PEER)

\section{Equation of motion}

The Lagrangian method is used to determine the equation of motion for single hinged compliant tower which is a type of energy method. The greatest advantage of using this approach is that it helps to avoid free-body diagram with environmental loading which is quite complex to analyse. The Cartesian coordinate system helps to describe global coordinates for the shaft. It is described in terms of degree of freedom by angle of rotation $\boldsymbol{\theta}$ and eliminates expression in terms of $\mathrm{X}-\mathrm{Y}$ coordinate system approach.

$$
\frac{\partial}{\partial t}\left(\frac{\partial K E}{\partial \dot{\theta}}\right)-\frac{\partial K E}{\partial \theta}+\frac{\partial P E}{\partial \theta}=M_{\theta}
$$

The position vector can be expressed for element ${ }^{e_{1 i}}$ at a distance ${ }^{r_{1 i}}$ from the base of compliant tower.

$$
\begin{aligned}
& x_{1 i}=r_{1 i} \sin \theta \\
& y_{1 i}=r_{1 i} \cos \theta
\end{aligned}
$$

And velocity is given by,

$$
\begin{aligned}
& \dot{x_{1 i}}=r_{1 i} \sin \theta \dot{\theta} \\
& \dot{y}_{1 i}=r_{1 i} \cos \theta \dot{\theta}
\end{aligned}
$$

acceleration is given by 


$$
\begin{gathered}
\ddot{x}=r \cos \theta \ddot{\theta}-r \sin \theta \dot{\theta}^{2} \\
\ddot{y}=-r \sin \theta \ddot{\theta}-r \cos \dot{\theta}^{2}
\end{gathered}
$$

Therefore, resultant Velocity

$$
\begin{gathered}
V=\sqrt{(r \cos \theta \dot{\theta})^{2}+(-r \sin \theta \dot{\theta})^{2}} \\
=\sqrt{\left(r^{2} \theta^{2}\right)\left(\cos ^{2} \theta+\sin ^{2} \theta\right)} \\
\mathrm{V}=\mathrm{r} \dot{\theta}
\end{gathered}
$$

Instantaneous Kinetic Energy of the Shaft is given by following expression

$$
\begin{gathered}
\text { K.E. }={ }^{\frac{1}{2} m V^{2}} \\
\text { Or KE }=\frac{1}{2}^{*} m(r \dot{\theta})^{2}
\end{gathered}
$$

Where ne is total number of elements of the tower, $\boldsymbol{m}^{*}$ is equal to structural mass and added mass. The added mass can expressed by the following

$$
\mathrm{am}=\left(C_{M}-1\right) \rho_{W} \frac{\Pi}{4} D^{2} d s
$$

Thus we can write KE is given by following Equations,

$$
K E=\frac{1}{2} \sum_{n e=1}^{n s e}(m s+m a)(r \dot{\theta})^{2}
$$

Kinetic energy of deck is given by

$$
K E=\frac{1}{2} m_{d}(l \dot{\theta})^{2}
$$

From equation (1) and (2) total kinetic energy is given by

$$
\begin{gathered}
\text { Total } K E=K E_{S H A F T}+K E_{D E C K} \\
K E=\frac{1}{2} \sum_{n e=1}^{n s e}{ }^{*}\left(m(r \dot{\theta})^{2}+\left(\frac{1}{2} m_{d}(l \dot{\theta})^{2}\right)\right)
\end{gathered}
$$

Differentiating total kinetic energy with respect to $\theta_{\text {will be zero, }}$

$$
\frac{\partial K E}{\partial \theta}=0
$$


On differentiating both sides w.r.t $\theta$

$$
\frac{\partial K E}{\partial \dot{\theta}}=\stackrel{*}{I} \dot{\theta}+I_{D} \dot{\theta}=\left(I+I_{D}\right) \dot{\theta}
$$

Again differentiating w.r.t time (t)

$$
\frac{\partial^{2} K E}{\partial t \partial \dot{\theta}}=\left(I+I_{D}\right) \ddot{\theta}
$$

Now potential Energy is given by

$$
P . E=\left(\sum_{i=1}^{n e}\left(m_{1 r} r_{1 r}\right)-\sum_{i=1}^{n e}\left(f_{1 r} r_{1 r}\right)\right) g \cos \theta
$$

Where $\mathrm{fb}=$ (buoyancy offered by an element) which is given by equation,

$$
f_{b}=\sum_{n e=1}^{n s e} \frac{\pi}{4}\left(\rho_{w}\right)\left(D_{\varepsilon B}\right)^{2}
$$

Deb $=$ Equivalent Diameter

Potential energy of deck is given by

$$
P E_{d}=m_{d}(l \cos \theta) g
$$

Now Total Potential energy is given by

$$
\text { T.pe }=\left(\sum_{i=1}^{n e}\left(m_{1 r} r_{1 r}\right)-\sum_{i=1}^{n e}\left(f_{1 r} r_{1 r}\right)\right) g \cos \theta+m_{d}(l \cos \theta) g
$$

Differentiating total potential energy with respect to $\theta$

$$
\begin{aligned}
& \frac{\partial \boldsymbol{P E}}{\partial \boldsymbol{\theta}}=-\left(\sum_{i=1}^{n e}\left(m_{1 r} r_{1 r}\right)-\sum_{i=1}^{n e}\left(f_{1 r} r_{1 r}\right)\right) g \operatorname{Sin} \theta+\left(-m_{d}(l \sin \boldsymbol{\theta}) g\right) \\
& \text { And Dissipation energy is given by } \\
& D \cdot E=\frac{1}{2} C V^{2} \\
& \text { Now } v=r \dot{\theta} \\
& \text { Therefore } D E=\frac{1}{2} C r^{2} \dot{\theta}^{2} \\
& \text { Differentiating with respect to } \dot{\theta} \\
& \frac{\partial D E}{\partial \dot{\theta}}=\frac{1}{2} C \times 2 \times \dot{\theta} \times r^{2} \\
& \frac{\partial D E}{\partial \dot{\theta}}=C r^{2} \dot{\theta}
\end{aligned}
$$

Putting the values from (3),(4) (5)and (6) in Lagrangian equation... 


$$
\begin{gathered}
\left(I+I_{D}\right) \ddot{\theta}+\left(-\sum_{i=1}^{n e}\left(m_{1 r} r_{1 r}\right)-\sum_{i=1}^{n e}\left(f_{1 r} r_{1 r}\right)\right) g \operatorname{Sin} \theta+\left(-m_{d}(l \sin \theta) g\right)+C r^{2} \dot{\theta}=M_{\theta} \\
\left(I^{*}+I_{D}\right) \ddot{\theta}+\left\{C r^{2}\right\} \dot{\theta}+\left\{-(F y+W x) \frac{\operatorname{Sin} \theta}{\theta}\right\} \theta=M_{\theta}
\end{gathered}
$$

Hence we can write derived Lagrangian equation in matrix for single degree of freedom as described below,

$$
M \ddot{\theta}+C \dot{\theta}+K \theta=M_{\theta}
$$

$\mathrm{M}$ is equal to the sum of moment of inertia of shaft of tower and the deck.

$\mathrm{K}$ is the function of sum of moments of the force and the weight of the structure.

$\mathrm{C}$ is the damping matrix, it is the function of material and hydrodynamic loading acting on the structure.

\section{Numerical Study}

The modelling of the structure has done considering a tower of $400 \mathrm{~m}$ in height. The depth of water is $350 \mathrm{~m}$ and it is divided in 50 finite elements of small size. These elements of the tower are assumed to have equal mass, area and volume. They are lumped at the nodes in order to analyse and calculate the restoring action, mass and moment of inertia about the base of the tower. The earthquake responses are analysed in moderate random sea waves has been performed. The moderate sea waves of height $4.5 \mathrm{~m}$ and it is considered to determine axial thrust, bending at critical section and top displacement of deck. The FORTAN programme is used to develop the source code EMAT and it is considered that the critical damping ratio is 3\% (Jain \& Dutta). The horizontal displacement of dynamic responses is considered while analysing the peak response. After the duration earthquake the time required to get the steady state responses is dependent on the sea state environment. Moderate random sea waves increase the damping of the seismic response and waves and current helps to stabilize the structure. The effect of changing the position and height of buoyancy chamber has been analysed taking into consideration extreme wave condition of $15 \mathrm{~m}$ height. After analysing for minimum angular and deck displacement. The tower is subjected to combination of simultaneous action of moderate wave and earthquake of small, moderate and large magnitudes. The current velocity is kept as $1.4 \mathrm{~m} / \mathrm{sec}$ in both the observations. 


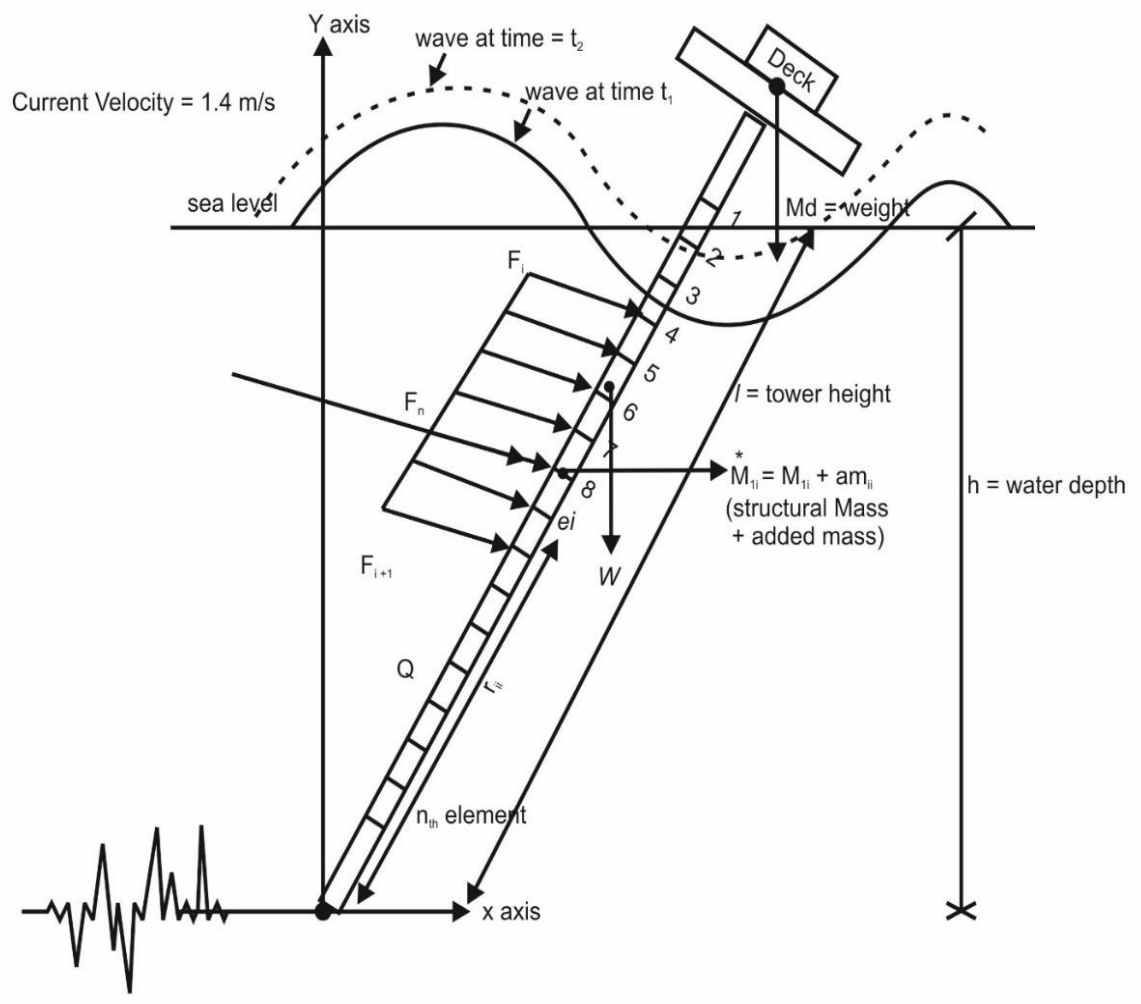

Fig. 3. SHAT model for analysis of response parameters.

\section{Results and discussion}

\subsection{Effect of earthquake on angular rotation}

The Comparative analysis is carried between near and far fault by considering small, moderate and large earthquakes. The Morgan hill near earthquake has angular rotation of 0.0359 radians where its far fault is found to have 0.0357 radians. which shows effect of near fault is more than far fault earthquake. But in case of far fault Imperial valley earthquake is found to be $1.38 \%$ higher angular rotation than its near fault. The Duzce Turkey near fault earthquake is having $7.81 \%$ higher angular rotation than its far fault. These parameters are very important while designing the offshore Compliant towers. We can see clearly that proper care is needed whether it is near or far fault as both of these can affect the structures severely.

\subsection{Displacement of the offshore tower during seismic loading}

Time domain analysis of the earthquake is done by considering various magnitudes of earthquakes in order to observe maximum deck displacement and other parameters. It is an important parameter in order to have safe design of offshore compliant towers and in terms of serviceability criteria also. The Morgan hill near fault is having maximum deck displacement of around $0.55 \%$ higher than far fault. Whereas it is quite interesting to note that in case of far fault moderate imperial valley earthquake the maximum variation of deck displacement is $1.62 \%$ higher than near fault earthquake. It clearly shows far fault earthquake may cause more damage as it depends on geometry, orientation of strike slip fault not generally on the distances. The Near Fault Duzce earthquake is having $6.29 \%$ higher variation than its Fault. 


\subsection{Shear force on base hinge}

The shear force acting on the offshore compliant tower is an important factor in design of hinges. The comparison is made between near and far fault earthquakes (Morgan Hill, Imperial Valley and Duzce Turkey) which are small, moderate and large earthquakes respectively. The base hinge shear force for Morgan hill is found to found to be $2.51 \%$ larger than its fault. Which is quite high and can cause more severe damage therefore utmost care should be taken regarding safety of the structure. The Duzce near fault earthquake is having $8.36 \%$ higher variation than its far fault.

\subsection{Axial force in base hinge}

The increase of axial thrust is the most important factor in order to analyse vertical ground motion that is heave motion. Figures shows variation Instantaneous Axial Responses for various Magnitudes of earthquakes along the shafts. Due to the presence of the huge mass of Deck there is compression in the shaft which is indicated by positive values. The part of the tower which is contact with the air with no buoyancy counters compressive forces. As soon as the tower comes in contact with the air buoyancy force comes into play in order to resist the compressive forces. This buoyancy forces increases with depth causing tension at the base of the tower. The imperial valley is having $0.28 \%$ higher variation of axial force than its near fault whereas the Duzce turkey near fault earthquake has 3.44\% higher instantaneous axial force. During drilling operations, it is important that there should be no vertical movement of the pipes which might can cause severe damage to the offshore tower therefore proper attention should be taken care in the design of offshore compliant structures.

\subsection{Effect of changing the position and height of buoyancy chamber are described below}

a) The effect of the changing the position of buoyancy chamber has been analysed taking into consideration the position $310 \mathrm{~m}, 290 \mathrm{~m}, 280 \mathrm{~m}$ and $270 \mathrm{~m}$ from the seabed.

b) It is found that the maximum angular rotation is changed from $1.681 \times 10^{-2}$ to $1.205 \times 10^{-2}$ radians when the positions is changed from $310 \mathrm{~m}$ to $270 \mathrm{~m}$ which clearly shows decrease in the movement of the deck.

c) The maximum deck displacement is found to decrease from 6.726 to 4.820 which is around $28 \%$ decrease when the position is changed from $310 \mathrm{~m}$ to $270 \mathrm{~m}$.

d) The maximum Instantaneous shear force is found to decrease from $7.09 \times 10^{6}$ to $4.43 \times 10^{6}$ decreasing the position from 310 to $270 \mathrm{~m}$. This shows effect of changing the position of buoyancy chamber on instantaneous shear force is not significant.

e) Similar results were obtained in case of maximum instantaneous Axial force and bending moment.

f) The effect of changing the height of buoyancy chamber were also observed as shown by the figures. It is found that the maximum bending moment, Axial and shear force does not change significantly.

g) The position of buoyancy chamber is taken as $270 \mathrm{~m}$ and height of buoyancy and ballast chamber is taken as $70 \mathrm{~m}$ and $120 \mathrm{~m}$ respectively after analysing the above results.

\begin{tabular}{|l|l|l|l|l|l|}
\hline $\begin{array}{l}\text { Position of } \\
\text { buoyancy } \\
\text { Chamber }\end{array}$ & $270 \mathrm{~m}$ & $280 \mathrm{~m}$ & $290 \mathrm{~m}$ & $300 \mathrm{~m}$ & $310 \mathrm{~m}$ \\
\hline $\begin{array}{l}\text { Hinge } \\
\text { Rotation(radians) }\end{array}$ & $\begin{array}{l}1.20520 \times 10- \\
2\end{array}$ & $\begin{array}{l}1.577522 \times 10- \\
2\end{array}$ & $\begin{array}{l}1.761232 \times 10- \\
2\end{array}$ & $\begin{array}{l}1.89816 \times 10- \\
2\end{array}$ & $\begin{array}{l}1.681606 \times 10- \\
2\end{array}$ \\
\hline $\begin{array}{l}\text { Deck } \\
\text { Displacement }\end{array}$ & $4.82096 \mathrm{~m}$ & $6.309827 \mathrm{~m}$ & $7.044556 \mathrm{~m}$ & $7.59230 \mathrm{~m}$ & $6.726109 \mathrm{~m}$ \\
\hline $\begin{array}{l}\text { Instantaneous } \\
\text { Shear force }\end{array}$ & $4.43 \times 10+6$ & $6.77 \times 10+5$ & $1.32 \times 10+6$ & $4.996 \times 10+6$ & $7.09 \times 10+6$ \\
\hline $\begin{array}{l}\text { Instantaneous } \\
\text { Axial force }\end{array}$ & $3.56 \times 10+7$ & $3.57 \times 10+7$ & $3.73 \times 10+7$ & $3.57 \times 10+7$ & $1.26 \times 10+10$ \\
\hline $\begin{array}{l}\text { Instantaneous } \\
\text { Bending moment }\end{array}$ & $1.19 \times 10+11$ & $1.48 \times 10+10$ & $3.56 \times 10+10$ & $1.10 \times 10+11$ & $3.57 \times 10+7$ \\
\hline $\begin{array}{l}\text { Shear force on } \\
\text { Base hinge }\end{array}$ & $4.94 \times 10+6$ & $1.82 \times 10+6$ & $2.38 \times 10+6$ & $4.99 \times 10+6$ & $4.27 \times 10+6$ \\
\hline $\begin{array}{l}\text { Axial force on } \\
\text { Base hinge }\end{array}$ & $1.77 \times 10+8$ & $2.01 \times 10+8$ & $2.01 \times 10+8$ & $2.01 \times 10+8$ & $1.80 \times 10+8$ \\
\hline
\end{tabular}

Fig. 4. Effect of changing the position of position of buoyancy chamber. 
7.6 Comparative Analysis between Moderate Northridge Earthquake (reverse fault) and Moderate Imperial Valley Earthquake (strike slip fault ).

\begin{tabular}{|l|l|l|l|l|l|}
\hline \multicolumn{1}{|c|}{ Parameters } & Mean & Median & Maximum & Minimum & $\begin{array}{l}\text { Standard } \\
\text { Deviation }\end{array}$ \\
\hline $\begin{array}{l}\text { Hinge } \\
\text { Rotation(radians) }\end{array}$ & -0.00000369 & 0.000476 & 0.0395 & -0.0430 & 0.0144 \\
\hline $\begin{array}{l}\text { Deck } \\
\text { Displacement }\end{array}$ & -0.00141 & 0.191 & 15.782 & -17.193 & 5.757 \\
\hline $\begin{array}{l}\text { Instantaneous } \\
\text { Shear force }\end{array}$ & 185003.800 & -277550.000 & 2765000.000 & -1114000.000 & 1247810.652 \\
\hline $\begin{array}{l}\text { Instantaneous } \\
\text { Axial force }\end{array}$ & -110558580.000 & -173250000.000 & -195300000 & -195300000 & 95158435.666 \\
\hline $\begin{array}{l}\text { Instantaneous } \\
\text { Bending moment }\end{array}$ & 26682202000 & 22820000000 & 63640000000 & 0.000 & $\begin{array}{l}21230187697 . \\
542\end{array}$ \\
\hline $\begin{array}{l}\text { Shear force on } \\
\text { Base hinge }\end{array}$ & -197415.569 & -87600.000 & 4910000.000 & -3210000.00 & 732534.398 \\
\hline $\begin{array}{l}\text { Axial force on } \\
\text { Base hinge }\end{array}$ & 175141354.071 & 174000000.000 & 196000000.0 & 153000000.000 & 3516116.642 \\
\hline
\end{tabular}

Fig. 5. Effect of Northridge Earthquake (reverse fault) on the response parameters of compliant model.

\begin{tabular}{|l|l|l|l|l|l|}
\hline Parameters & Mean & Median & Maximum & Minimum & $\begin{array}{l}\text { Standard } \\
\text { Deviation }\end{array}$ \\
\hline $\begin{array}{l}\text { Hinge } \\
\text { Rotation(radians) }\end{array}$ & 0.000307 & 0.000419 & 0.0365 & -0.0384 & 0.0141 \\
\hline $\begin{array}{l}\text { Deck } \\
\text { Displacement }\end{array}$ & 0.123 & 0.168 & 14.612 & -15.353 & 5.654 \\
\hline $\begin{array}{l}\text { Instantaneous } \\
\text { Shear force }\end{array}$ & 229332.400 & -131150 & 2490000 & -885000 & 1056801.577 \\
\hline $\begin{array}{l}\text { Instantaneous } \\
\text { Axial force }\end{array}$ & -111178800 & -174000000 & 35800000 & -196000000 & 95273489.163 \\
\hline $\begin{array}{l}\text { Instantaneous } \\
\text { Bending moment }\end{array}$ & 23870700000 & 20400000000 & 55900000000 & 0.000 & 18364121742.058 \\
\hline $\begin{array}{l}\text { Shear force on } \\
\text { Base hinge }\end{array}$ & -172758.408 & -59050.000 & 5830000.000 & -2590000.0 & 409227.692 \\
\hline $\begin{array}{l}\text { Axial force on } \\
\text { Base hinge }\end{array}$ & 175142556.874 & 174000000.000 & 1800000000.0 & 171000000.000 & 1626365.248 \\
\hline
\end{tabular}

Fig. 6. Effect of Imperial valley (strike slip) on the response parameters of compliant model.

- The Comparative analysis is made between reverse and strike slip far faults. It is found that maximum instantaneous bending moment in case of Northridge earthquake is around $6363 \times 107$ where as in case of Imperial Valley earthquake it is around 5590X107 Which is almost $12.16 \%$ higher in case of reverse fault.

- The maximum instantaneous shear force in case of Northridge reverse fault is found to be 2765000 and in case of Imperial valley strike slip fault it is found to be 2490000 which is $11.40 \%$ higher in case of reverse Fault.

- This indicates the effect of reverse fault is more severe than strike slip fault proper soil ground investigation is very important before commencement of offshore project along these fault zones.

- The angular rotation characterizes the safe design and serviceability criteria. In case of strike fault, it is found to be 0.0395 radians whereas in case of strike slip fault, it is found to be 0.0365 radians which is $7.59 \%$ higher in case of Northridge earthquake. Similar results are obtained in maximum top displacement of deck which is found to be $7.41 \%$ higher than strike slip fault.so proper investigation is needed regarding orientation of fault and soil condition. 


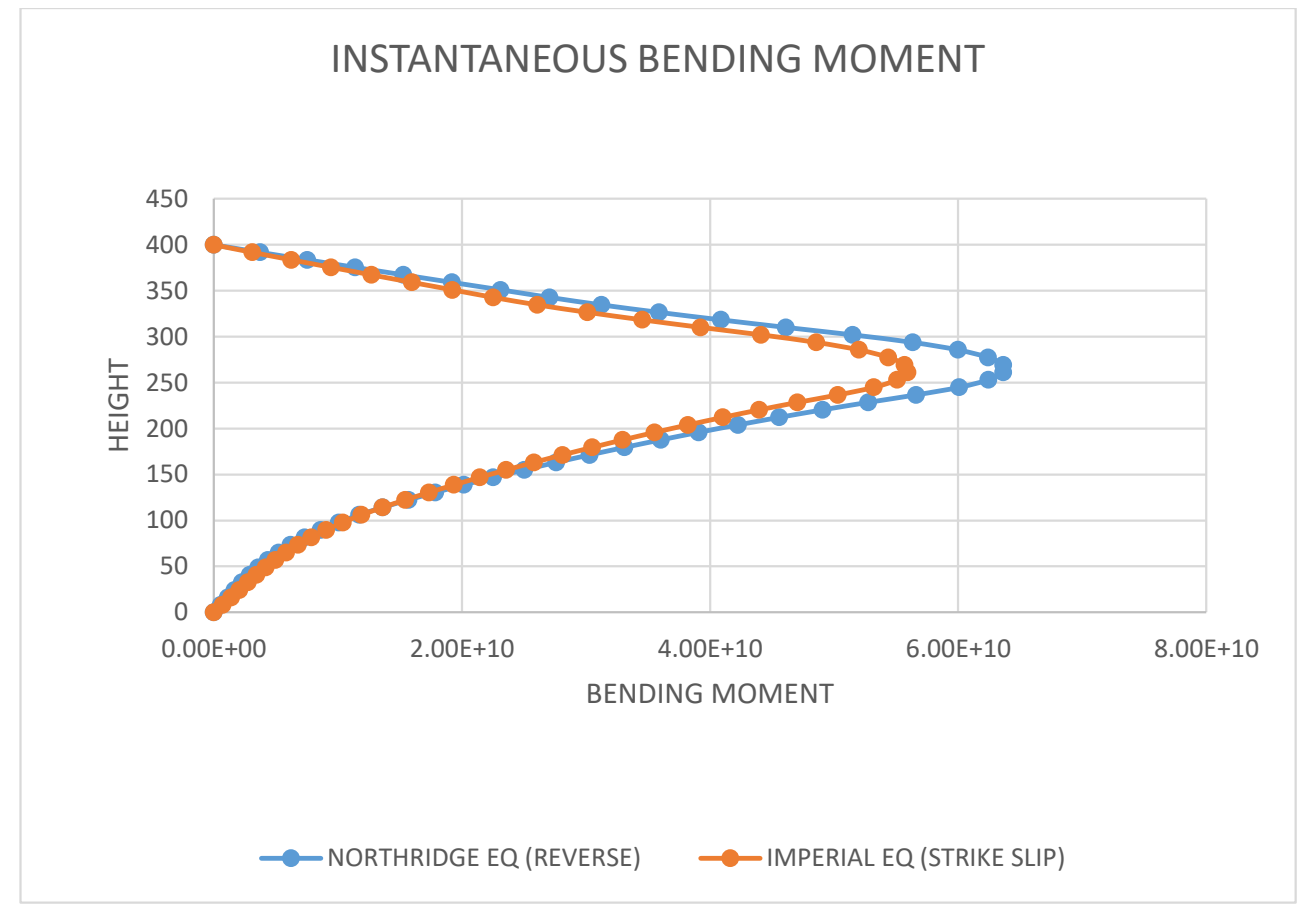

Fig. 7. Comparison of instantaneous bending moment for reverse and strike slip fault.

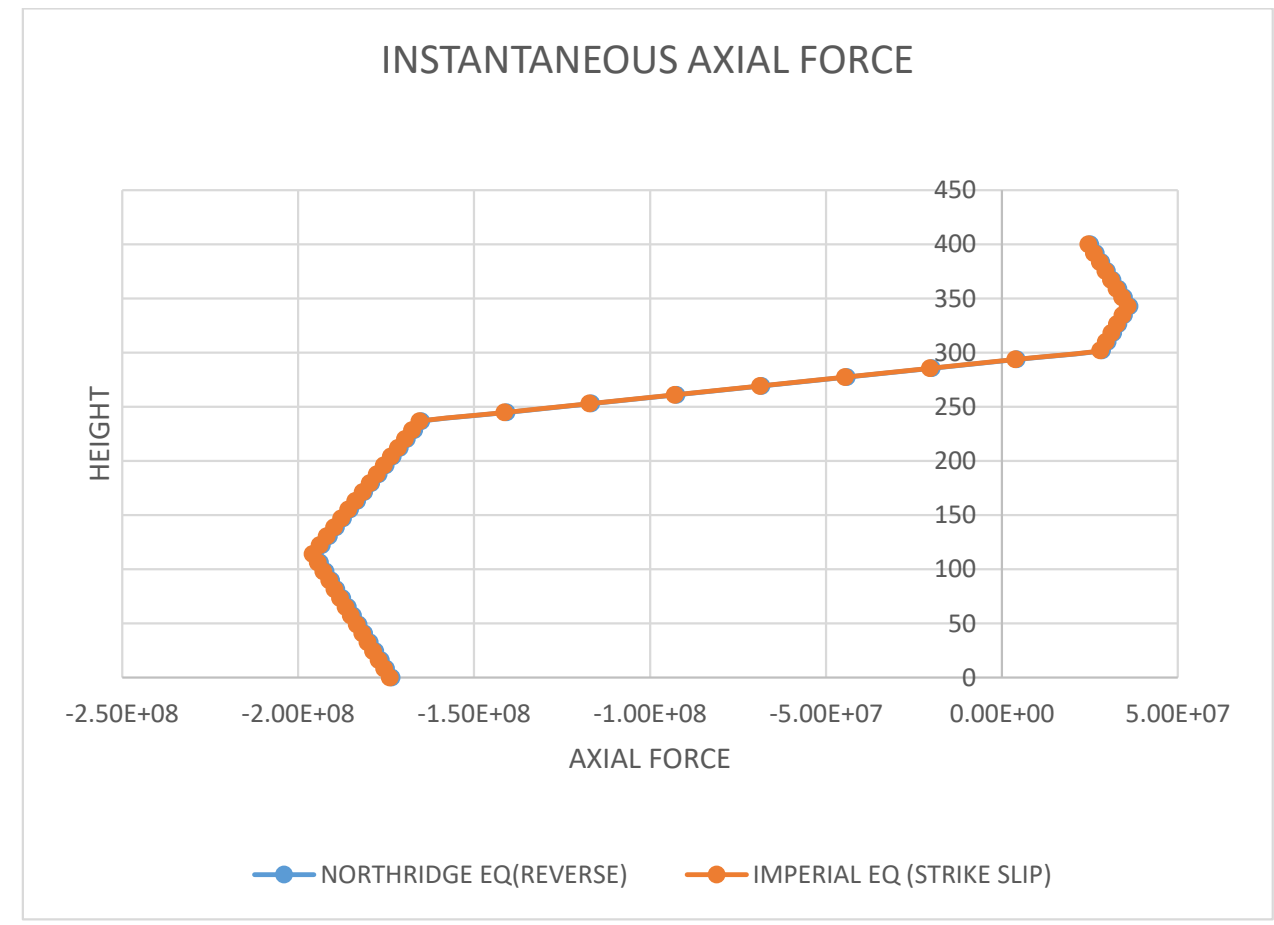

Fig. 8. Comparison of instantaneous shear, axial force of reverse and strike-slip fault. 

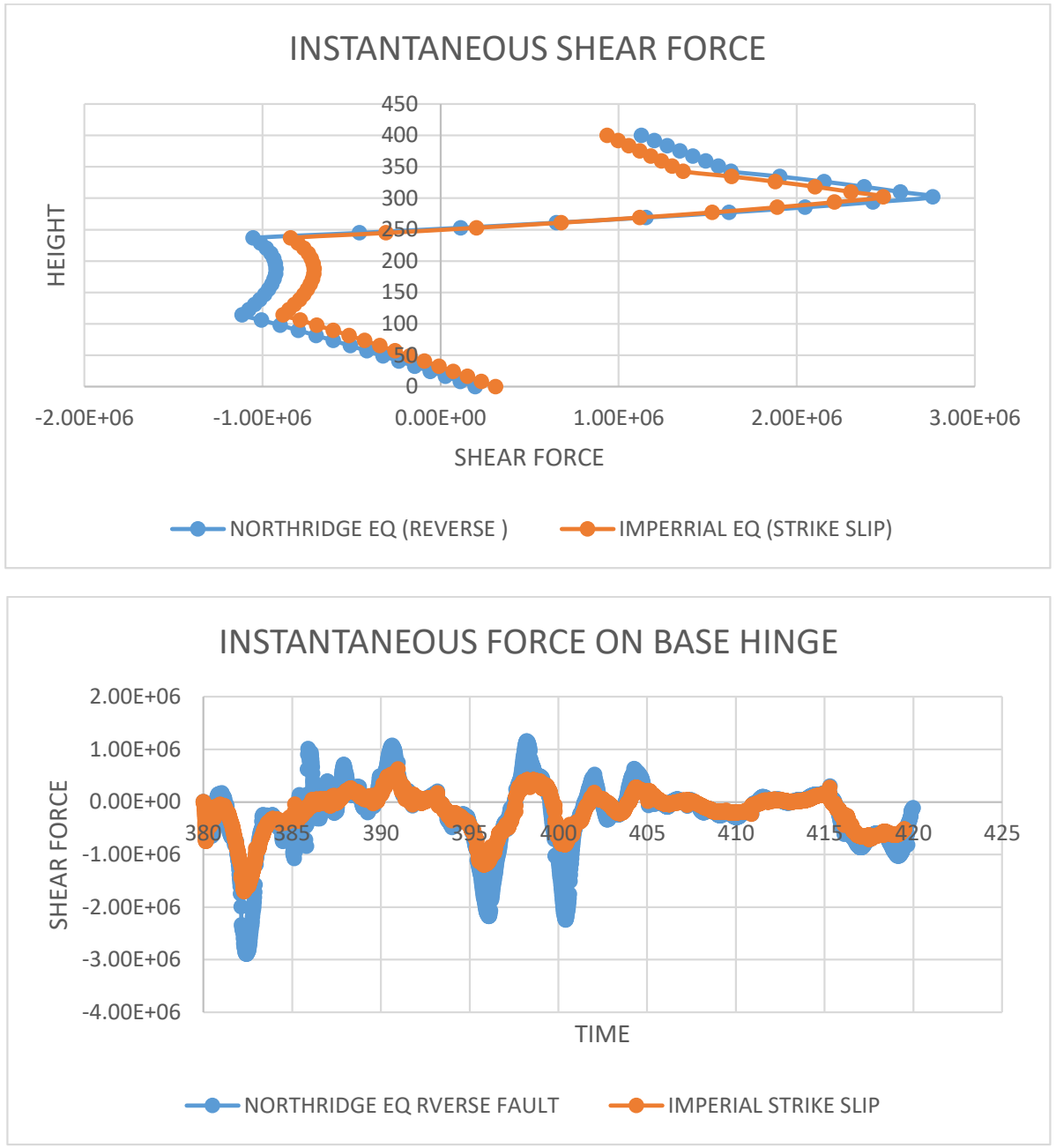

Fig. 9. Comparison of shear force on base hinge of reverse and strike-slip fault.

\subsection{Comparative study between moderate and extreme wave}

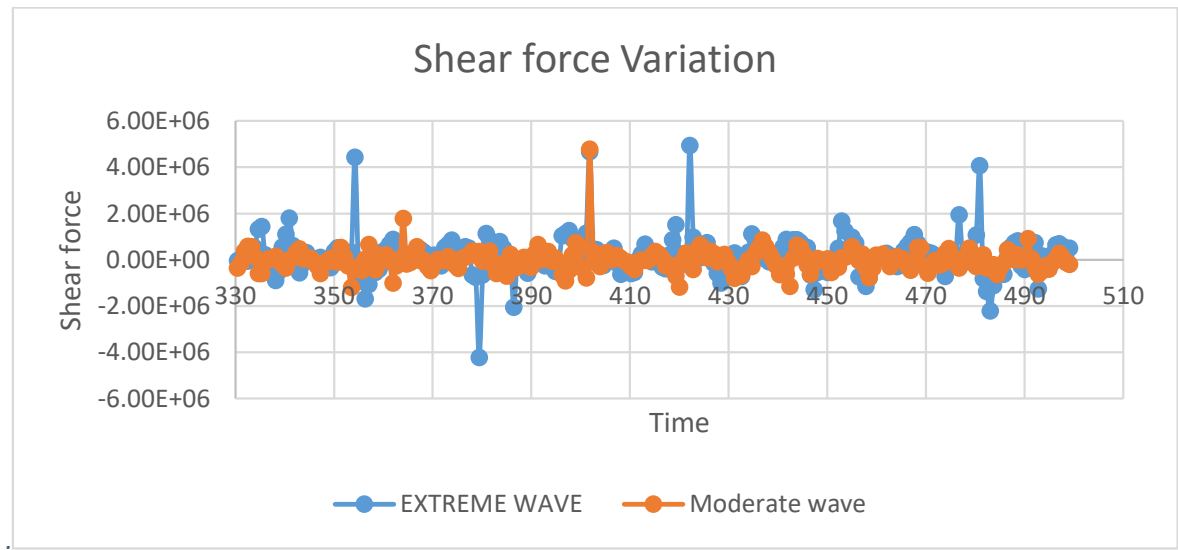

Fig. 10. Comparative analysis of shear force on base hinge for extreme and moderate waves 
- The maximum hinge rotation due to extreme random wave is observed to be $81.8 \%$ as compared to moderate wave. Similar observation is concluded in case of deck displacement which is $82.08 \%$ higher than moderate random wave.

- The maximum Instantaneous Shear, axial and Bending moment are also observed to be quite high as compared to moderate random wave but the effect of extreme wave is not much significant on shear and axial on base hinge of compliant model.

\subsection{Effect of extreme wave and moderate wave on the parameters of compliant offshore model}

\begin{tabular}{|l|l|l|l|l|l|}
\hline Parameters & Mean & Median & Maximum & Minimum & $\begin{array}{l}\text { Standard } \\
\text { Deviation }\end{array}$ \\
\hline $\begin{array}{l}\text { Hinge } \\
\text { Rotation(radians) }\end{array}$ & -0.000789 & -0.000727 & 0.0311 & -0.0394 & 0.00928 \\
\hline $\begin{array}{l}\text { Deck } \\
\text { Displacement }\end{array}$ & -0.315 & -0.290 & 12.440 & -15.734 & 3.710 \\
\hline $\begin{array}{l}\text { Instantaneous } \\
\text { Shear force }\end{array}$ & 314576.000 & 2259156.188 & 4432000.000 & -1730000.0 & 2259156.188 \\
\hline $\begin{array}{l}\text { Instantaneous } \\
\text { Axial force }\end{array}$ & - & -173900000.0 & 35640000.00 & -196000000 & 95195866.888 \\
\hline $\begin{array}{l}\text { Instantaneous } \\
\text { Bending moment }\end{array}$ & 52445426000.0 & 44815000000 & 119100000000 & 0.000 & 40753096066.78 \\
\hline $\begin{array}{l}\text { Shear force on } \\
\text { Base hinge }\end{array}$ & 171925.579 & 136000.000 & 4940000.0 & -4220000.0 & 876611.900 \\
\hline $\begin{array}{l}\text { Axial force on } \\
\text { Base hinge }\end{array}$ & 175053719.008 & 174000000.0 & 177000000.00 & 171000000.0 & 1962619.188 \\
\hline
\end{tabular}

Fig. 11. Effect of Extreme wave on the response parameters of SHAT model.

\begin{tabular}{|l|l|l|l|l|l|}
\hline Parameters & Mean & Median & Maximum & Minimum & $\begin{array}{l}\text { Standard } \\
\text { Deviation }\end{array}$ \\
\hline $\begin{array}{l}\text { Hinge } \\
\text { Rotation(radians) }\end{array}$ & -0.0000390 & 0.000139 & 0.0171 & -0.0218 & 0.00463 \\
\hline $\begin{array}{l}\text { Deck } \\
\text { Displacement }\end{array}$ & -0.0156 & 0.0555 & 6.834 & -8.705 & 1.853 \\
\hline $\begin{array}{l}\text { Instantaneous } \\
\text { Shear force }\end{array}$ & 325393.60 & 149150.000 & 1386000.0 & -272200.00 & 573682.406 \\
\hline $\begin{array}{l}\text { Instantaneous } \\
\text { Axial force }\end{array}$ & -113831696.0 & -177000000.00 & 34130000.00 & -199100000.0 & 95854929.179 \\
\hline $\begin{array}{l}\text { Instantaneous } \\
\text { Bending moment }\end{array}$ & 19122320000.00 & 18165000000 & 38050000000 & 0.000 & 12221697429.52 \\
\hline $\begin{array}{l}\text { Shear force on } \\
\text { Base hinge }\end{array}$ & -20986.897 & -26050.000 & 4780000.00 & -1200000.0 & 487777.203 \\
\hline $\begin{array}{l}\text { Axial force on } \\
\text { Base inge }\end{array}$ & 175090909.091 & 174000000.000 & 177000000.0 & 174000000.00 & 1446128.040 \\
\hline
\end{tabular}

Fig. 12. Effect of moderate wave on response parameters of SHAT model. 


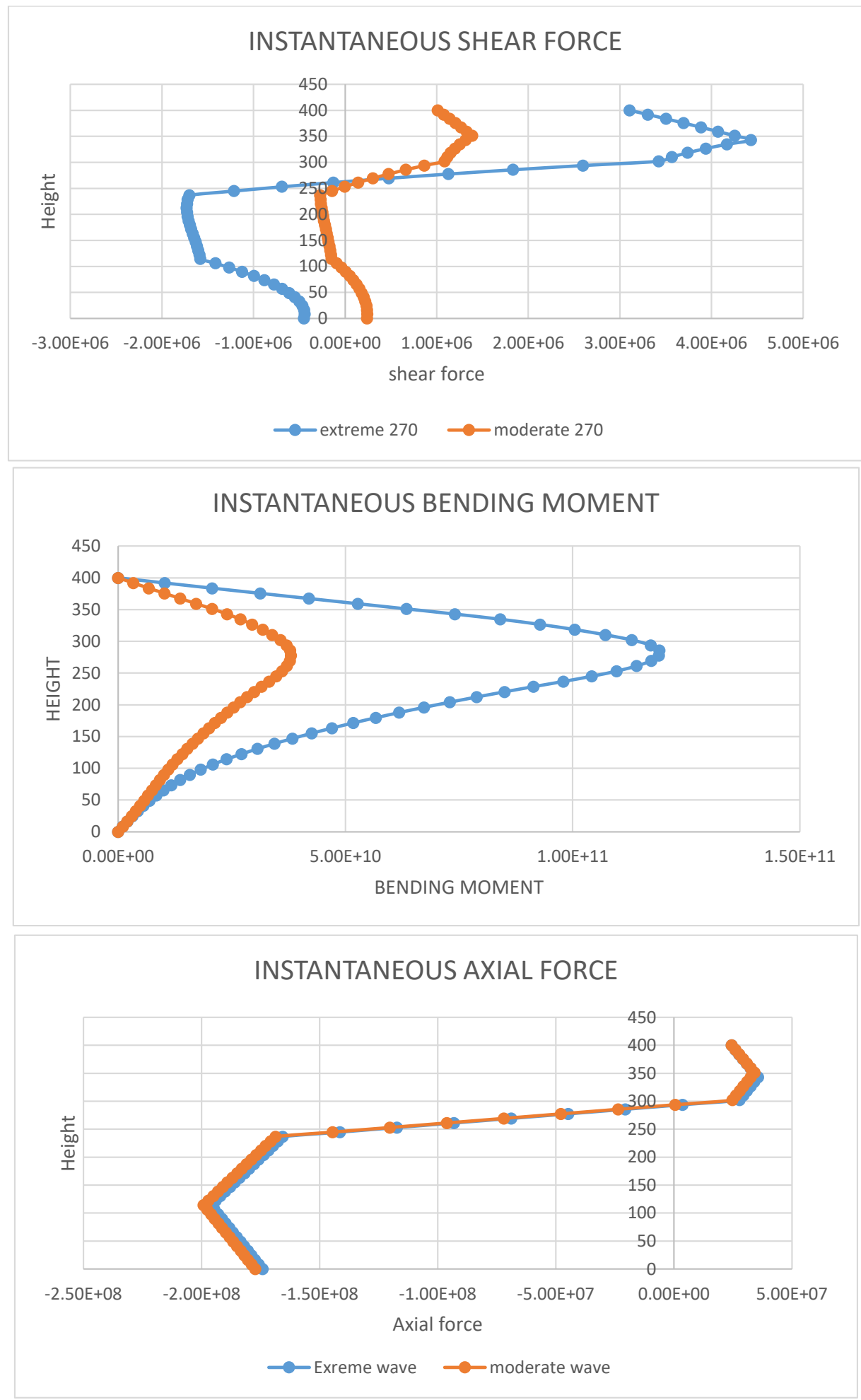

Graph. 1. Comparative analysis of instantaneous variation of shear, axial, bending moment for extreme and moderate waves. 


\section{Conclusion}

1. It is observed that the far fault can cause severe damage as compared to near fault as it does not depend on the location of earthquake from the structure but also on the orientation and geometry of fault.

2. The reverse fault has more severe effect then strike slip fault as concluded by comparing Northridge and Imperial Valley Earthquake.

3. The response parameters taken with the selected ground acceleration time histories like shear and axial force acting on the base hinge are having magnitude in the order of $10^{5} \mathrm{~N}$ in case of both near and far fault earthquakes. Hence the seismic analysis for the compliant offshore tower is important in order to ensure safety and serviceability of these type of structures.

4. The effect of changing the height of buoyancy chamber is not much significant in comparison to the effect of changing the buoyancy chamber when we apply only extreme random waves.

5. After applying the earthquakes of various magnitudes. It is concluded that the tower is vibrating at its natural frequency and the stabilization of tower takes place after the earthquake is over as the waves dampens its effect.

6. The maximum instantaneous shear, axial force is observed to be different as compared to maximum shear and axial force acting on the base hinge. For example, in case of Morgan near fault earthquake the maximum Instantaneous shear force is more than the shear force acting on the hinge. This should be taken care while designing the compliant offshore structure as the local maximum force acting on the structures is more than the maximum global force.

7. The effect of extreme wave on the deck displacement and hinge rotation is found to be 3 to 4 times than moderate random wave but the shear and axial force acting on the base hinges is only $3.5 \%$ to $4 \%$ due to extreme random waves as compared to moderate wave.

\section{Further Suggestions regarding future work}

8. The effect of Reverse fault as compared to strike slip fault can be done by considering various magnitudes of earthquake on the response parameters of offshore compliant model.

9. Comparison can be made between Stokes and Cnoidal wave theories and they can also be used to calculate vertical and horizontal component of velocity and acceleration that is sea state elevation.

10. Considering the response parameters calculated above, design of hinge of compliant offshore structure can be suggested.

11. Effect of changing the height of moderate wave during the earthquake on the response parameters of model can also be analysed.

\section{References}

1. Banik, A.K., "Dynamic stability analysis of compliant offshore structures", PhD. Thesis, IIT, Delhi, 2004

2. Chakrabarti S.K., "Stability analysis of interaction of an articulated tower with waves", Proceedings of Fluid interaction, Heikidiki, Greece. Vol.1, pp.281-292, 2001.

3. Chakrabarti, S. and Cotter, D., "Motion analysis of articulated tower" journal of waterway, port, coastal and ocean division, ASCE, Vol.105, pp.281-292, 1979.

4. Jain, A.k., and Datta, T.k, (1991). Non-linear behaviour of articulated tower in random sea 'J.Eng.Ind.,238-240.

5. Islam, N., and Ahmad, (2006). Earthquake response of articulated tower.' European Earthquake Engineering 1.48-58. 